\title{
Lysine Production of Microbacterium lacticum by Submerged Fermentation Using Various Hydrocarbon, Sugar and Nitrogen Sources
}

\author{
C. C. Ezemba1*, C. A. Ozokpo², V. N. Anakwenze², G. C. Anaukwu², C. M. Ogbukagu², C. C. Ekwealor' \\ I. A. Ekwealor ${ }^{2}$ \\ ${ }^{1}$ Department of Microbiology, Renaissance University, Ugbawka, Nigeria \\ ${ }^{2}$ Department of Applied Microbiology and Brewing, Nnamdi Azikiwe University Awka, Awka, Nigeria \\ Email: *constancechinyere790@yahoo.com
}

How to cite this paper: Ezemba, C.C., Ozokpo, C.A., Anakwenze, V.N., Anaukwu, G.C., Ogbukagu, C.M., Ekwealor, C.C. and Ekwealor, I.A. (2016) Lysine Production of Microbacterium lacticum by Submerged Fermentation Using Various Hydrocarbon, Sugar and Nitrogen Sources. Advances in Microbiology, 6, 797-810. http://dx.doi.org/10.4236/aim.2016.611078

Received: February 22, 2016

Accepted: September 4, 2016

Published: September 7, 2016

Copyright $\odot 2016$ by authors and Scientific Research Publishing Inc. This work is licensed under the Creative Commons Attribution International License (CC BY 4.0).

http://creativecommons.org/licenses/by/4.0/

\begin{abstract}
Bacterial isolation from oil-contaminated and uncontaminated soil was screened for hydrocarbon utilizer which was also capable of producing lysine. Microbial production of lysine by Microbacterium lacticum was investigated in submerged fermentations using various concentrations of hydrocarbon, sugar sources and nitrogen. Of the nine sugar and five nitrogen sources tested, glucose/ammonium sulphate proved optimum for lysine production. Effect of varying concentration of carbon and nitrogen sources on lysine accumulation showed that glucose (4\%) ammonium sulphate (1\%) respectively increased lysine production. A gram positive rod bacterium identified as Microbacterium lacticum was identified. Optimizing the cultural conditions of Microbacterium lacticum in submerged medium gave a methionine yield of 2.99 $\mathrm{mg} / \mathrm{ml}$ lysine in the broth culture after $96 \mathrm{~h}$.
\end{abstract}

\section{Keywords}

Lysine, Microorganism, Submerged Medium, Soil, Microbacterium lacticum

\section{Introduction}

Lysine is one of the nine essential and commercially important amino acids, out of the twenty naturally occurring amino acids. It is a basic building block of all protein. This amino acid was first isolated in 1889 from casein. Lysine is an essential amino acid required mainly by children and growing animals. Lysine cannot be synthesized biologically in the body and its breakdown is irreversible [1], but may be added to food and feed materials to improve the protein quality [2]. Hence it must be ingested as lysine or 
lysine-containing proteins [3]. Bread is enhanced by the addition of lysine [4]. It plays an essential role in the production of carnitine, a nutrient responsible for converting fatty acids into energy and helping to lower cholesterol. It also helps the immune system ward off viral infections, like herps, cold sore, mouth ulcers and the associated fever [5].

Children and growing animals require high levels of lysine for bone formation, adequate milk production and proper growth [6]. Lysine is used as food (flavour) enhancer and also food preservation especially with ${ }^{\varepsilon}$-poly-L-lysine [7].

Lysine production processes by microorganism have been investigated by many researchers [8]-[10]. L-lysine can be produced chemically, enzymatically and biochemically just like other amino acids. The biochemical process is more practical, economic and optical active, even though relatively low yields are obtained during the extraction of L-lysine. Chemical synthesis of lysine gives more yield and requires specific installations and the use of expensive products [11] [12].

The production of lysine by fermentation began with a technique developed by the Chas-Pfizeranco laboratories in 1956. It has been developed into a commercial process and it has been widely used in Japan, USA, France [13] and several hundred thousand tones of L-lysine are annually produced worldwide almost by microbial fermentation [12]. The sterospecificity (the L-isomer) of amino acids and the steadily increasing L-lysine demand necessitates indispensably their fermentative production (the $\mathrm{L}$ isomer) over synthetic processes [12].

A number of microorganisms capable of producing amino acids have been isolated and amino acids such as threonine, isoleucine, histidine and methionine have been produced successfully by fermentation [14]-[16]. Attempts have been made to overproduce biological active L-lysine using fermentation [17]-[19].

This work was therefore carried out to study microorganisms that are capable of metabolizing hydrocarbon and equally produce lysine; to determine the factors that will stimulate growth and appreciably enhance lysine accumulation and the time taken for the optimum production of lysine by Microbacterium lacticum. In this study, under submerged fermentation, an active isolate identified as Microbacterium lacticum, gave the highest lysine production and then studied. No production of lysine by Microbacterium species has been reported. Although [20] noted that the yielding strains are found mostly among species of Arthrobacter, Corynebacterium and Brevibacterium.

\section{Material and Methods}

\subsection{Isolation of Bacteria}

Soil samples from oil contaminated and uncontaminated area samples were collected in sterile screw capped bottles from at the soil depth of $2-8 \mathrm{~cm}$. both obtained in South-eastern part of Nigeria. Two grams of each soil samples was serially diluted in ten- folds in sterile distilled water. One drop of each hydrocarbon (kerosene, gasoline, motor oil, spent oil and crude oil) and $0.1 \mathrm{ml}$ of $10^{-5}$ dilutions of soil sample were introduced into $10 \mathrm{ml}$ of sterilized basal medium respectively. The basal medium, con- 
sisting of: $\mathrm{NaCl}, 0.4 \mathrm{~g} ; \mathrm{NH}_{4} \mathrm{Cl}, 0.5 \mathrm{~g} ; \mathrm{MgSO}_{4} \cdot 7 \mathrm{H} 2 \mathrm{O}, 0.5 \mathrm{~g} ; \mathrm{KH}_{2} \mathrm{PO}_{4}, 0.05$ g, distilled $\mathrm{H}_{2} \mathrm{O}$, I L and $\mathrm{NaHPO}_{4} \cdot 7 \mathrm{H}_{2} \mathrm{O}, 0.05 \mathrm{~g}$ Ward and Brock [21]. The tubes were incubated at $30^{\circ} \mathrm{C}$ for 7 days. Purity test of the first stock culture were carried out by the ordinary culture technique using basal media mentioned above, which $2 \%$ agar was added. The carbon source consisted of $0.5 \mathrm{ml}$ of the hydrocarbons added to a sterile filter paper secured in the lids of 70 by $15 \mathrm{~mm}$-diameter sterile Petri dishes under aseptic condition. The dishes was then inverted and incubated at $30^{\circ} \mathrm{C}$ for 4 days. The pure isolate were transferred onto Nutrient agar (Oxoid) slants and stored at $4^{\circ} \mathrm{C}$ for further studies.

\subsection{Preliminary Screening of Isolates for Lysine Production on Solid Medium}

The isolates were screened for lysine production by the method described by Hallsall [22] Sterilized plates of the minimal agar medium containing: $\mathrm{KH}_{2} \mathrm{PO}_{4}, 1.36 \mathrm{~g}$; $\left(\mathrm{NH}_{4}\right)_{2} \mathrm{SO}_{4}, 2.0 \mathrm{~g} ; \mathrm{MgSO}_{4} \cdot 7 \mathrm{H}_{2} \mathrm{O}, 0.2 \mathrm{~g} ; \mathrm{CaCl}_{2}, 0.01 \mathrm{~g} ; \mathrm{FeSO}_{4} \cdot 7 \mathrm{H}_{2} \mathrm{O}, 0.5 \mathrm{mg}$; Glucose, $2.0 \mathrm{~g}$; Agar, $12 \mathrm{~g}$; distilled $\mathrm{H}_{2} \mathrm{O}, 1 \mathrm{~L}, \mathrm{pH}$ adjusted to 7.2 with $1 \mathrm{~N}$ of $\mathrm{NaOH}$ and sterilized at $121^{\circ} \mathrm{C}$ for 15 minutes. The minimal agar medium seeded with $24 \mathrm{~h}$ broth culture of lysine auxotrophs, Escherichia coli (DSM 1099 and DSM 5210) was, spread inoculated with each soil isolate. After $72 \mathrm{~h}$ incubation of the plates at $30^{\circ} \mathrm{C}$, isolates showing halo growth of the auxotroph were sub-cultured and used for further studies. These isolates produced lysine on solid medium and were termed lysine producers.

\subsection{Screening Lysine Producers in Submerged Medium with Different Carbon and Nitrogen Sources}

Seed inoculums: A loopfuls of a $24 \mathrm{~h}$ culture of the lysine-producer was inoculated into a test tube containing $5 \mathrm{ml}$ of the seed medium (Peptone, $10.0 \mathrm{~g}$; Yeast extract, $10.0 \mathrm{~g}$; $\mathrm{NaCl}-5.0$ g; distilled $\mathrm{H}_{2} \mathrm{O}-1$ litre). The test tube was incubated for $18 \mathrm{~h}$ on a shaker $(120 \mathrm{rpm})$ at $30^{\circ} \mathrm{C}$.

Fermentation: The basal medium for fermentation is composed of: $\mathrm{KH}_{2} \mathrm{PO}_{4}, 1.0$ g; $\mathrm{MgSO}_{4} \cdot 7 \mathrm{H}_{2} \mathrm{O}, 0.4 \mathrm{~g} ; \mathrm{MnSO}_{4} \cdot \mathrm{H}_{2} \mathrm{O}, 2.0 \mathrm{mg} ; \mathrm{FeSO}_{4} \cdot 7 \mathrm{H}_{2} \mathrm{O}, 2.0 \mathrm{mg} ; \mathrm{CaCO}_{3}, 50.0 \mathrm{~g}$; distilled $\mathrm{H}_{2} \mathrm{O}, 1 \mathrm{~L}$, pH 7.2 with $1 \mathrm{~N} \mathrm{NaOH}$. Glucose, $20.0 \mathrm{~g}$ and $\left(\mathrm{NH}_{4}\right)_{2} \mathrm{SO}_{4}, 10.0 \mathrm{~g}$; served as a carbon and nitrogen sources respectively, and the medium sterilized at $115^{\circ} \mathrm{C}$ for 10 min. one milliliter volume of the seed inoculum (Ca $\left.5.6 \times 10^{8} \mathrm{cells} / \mathrm{ml}\right)$ was inoculated into duplicate $100 \mathrm{ml}$ Erlenmeyer flask containing $20 \mathrm{ml}$ of fermentation medium. Duplicate flask were prepared and incubated at $30^{\circ} \mathrm{C}$ for $72 \mathrm{~h}$ in a rotary shaker at 160 $\mathrm{rpm}$. Uninoculated flasks were served as control.

The carbon (Glucose, Sucrose, Lactose, Fructose, Kerosene, Gasoline, Motor oil, Spent oil, Crude oil) and nitrogen ( $\mathrm{NH} 4)_{2} \mathrm{SO}_{4}, \mathrm{NH}_{4} \mathrm{CL}, \mathrm{KNO}_{3}, \mathrm{NH}_{4} \mathrm{H}_{2} \mathrm{PO}_{4}$ ) sources were replaced and fermentation process carried out as previously described. The most lysine producer was investigated. The carbon/nitrogen source with the highest lysine yield was used for further studies. Optimization studies were equally conducted.

Determination of Growth: Growth of the isolate was determined turbidimetrically from the culture broth using JENWAY Spectrophotometer (Model $6405 \mathrm{uv} / \mathrm{vis}$ ) at 660 nm. 
L-Lysine Assay: Quantitative estimation of L-lysine in the supernatant was carried out by acid ninhydrin method of Chinard [23]. A $5 \mathrm{ml}$ volume of the culture broth was centrifuged at $5000 \times \mathrm{g}$ for $20 \mathrm{~min}$ and the cell-free supernatant was assayed for L-lysine. One $\mathrm{ml}$ of glacial acetic acid was added to $1 \mathrm{ml}$ of the supernatant in a test tube followed by the addition of $1 \mathrm{ml}$ of a reagent solution which contains an acid mixture of $0.4 \mathrm{ml}$ of $6 \mathrm{M}$ orthophosphoric acid, $0.6 \mathrm{ml}$ of glacial acetic acid and $25 \mathrm{mg}$ of ninhydrin per millilitre of the acid mixture. The blank test tube were similarly prepared but without ninhydrin. Both test tubes were capped and the content mixed properly before heating at $100^{\circ} \mathrm{C}$ in a water bath for $1 \mathrm{~h}$. and then cooled. A $2 \mathrm{ml}$ of glacial acetic acid added to each tube to give a final volume of $5 \mathrm{ml}$. The optical density of the reacting mixture (tube with ninhydrin) was read against the blank at $515 \mathrm{~nm}$ in a spectrophotometer (Jenway spectrophotometer model 6405 uv/vis). Lysine concentration was extrapolated from a standard lysine curve. The standard lysine curve was obtained by plotting the values of optical densities against the concentrations $(0.1 \mathrm{mg} / \mathrm{ml}$ to 0.9 $\mathrm{mg} / \mathrm{ml}$ ) of standard lysine solutions.

\subsection{Estimation of Reducing Sugar}

The residual sugar (glucose) in the time- course fermentation broth was estimated following the method described by Miller [23]. A $1 \mathrm{ml}$ volume of dinitrosalicylic acid was added and $1 \mathrm{ml}$ of the supernatant in a test tube was heated in boiling water for $10 \mathrm{~min}$. The tube was rapidly cooled, and the volume adjusted to $12 \mathrm{ml}$ with distilled water. A blank test tube containing of distilled water and $1 \mathrm{ml}$ of dinitrosalicylic acid was similarly prepared. The optical density of the mixture was read at $540 \mathrm{~nm}$ in a spectrophotometer. Glucose concentration in the supernatant was estimated from a glucose standard curve.

\subsubsection{Identification of Active Lysine Producer}

Methods described by [24]-[27] were used for characterization of the active isolate. Colony morphology on Nutrient agar, biochemical and physiological test such as Gram reaction, Motility, Nitrate reduction, sugar, citrate and tyrosine utilization and $\mathrm{NaCl}$ tolerance were examined.

\subsubsection{Time Course Experiment for Growth, $\mathrm{PH}$, Sugar Utilization and Lysine Production}

Time course experiment for growth, $\mathrm{pH}$, sugar utilization and methionine production by Microbacterium lacticum, was studied. The fermentation medium consists of basal medium, Glucose, $40 \mathrm{~g}$; $\left(\mathrm{NH}_{4}\right)_{2} \mathrm{SO}_{4}, 10 \mathrm{~g}$; a mixture of yeast extract, peptone, casein, 0.1\% (w/v); Biotin, $1.0 \mu \mathrm{g} / \mathrm{ml} ; \mathrm{Sr}^{2+}, 5.0 \mu \mathrm{g} / \mathrm{ml}$; L-methionine, 0.01\% (w/v); $\mathrm{H}_{2} \mathrm{O} 1 \mathrm{~L} ; \mathrm{pH}$ 7.2. Fermentation process was carried out as previously described and growth determined turbidimetrically with a spectrophotometer at $660 \mathrm{~nm}$. Lysine concentration in the broth culture was determined as previously described and sugar utilization estimated following the method described by Chinard [23]. Statistical analysis: Data obtained were subjected to statistical analysis (one-way ANOVA) using Statistical Package 
for Social Science (SPSS) 15.0 for Windows Evaluation, Version 2006. P-values $<0.05$ were considered statistically significant.

\section{Results}

\subsection{Identification of Active Lysine Producer}

Growth on 24 h Nutrient agar plates showed yellow-white creamy colonies with wavy margins. They are gram positive with irregular slender rods arranged singly. Catalase, Motility, Nitrate reduction, Citrate, Urease indole were positive while spore stain, Methly red, Oxidase and phenylalanine were negative. Sugar utilized includes glucose, maltose, fructose but lactose, mannitol, galactose, sucrose, dulcitol and D-xylose were not used and tyrosine was utilization and sodium chloride $(\mathrm{NaCl})$ tolerance $>9 \%$, $<10 \%$. The organism was identified as a strain of Microbacterium lacticum.

\subsection{Effect of Medium/Fermenter Volume Ratio on Lysine Production}

The effects of medium/fermenter volume ratio (volume of the culture medium: volume of fermentation flask) lysine production by Microbacterium lacticum are shown in Figure 1. Erlenmeyer flasks $(100 \mathrm{ml})$ with different volumes $(15,20,25,30 \mathrm{ml})$ of the sterile fermentation medium were each inoculated with $1 \mathrm{ml}$ of seed inoculum. The results show that $20 \%$ medium volume gave the highest concentration of $(1.47 \mathrm{mg} / \mathrm{ml})$ lysine. Thus $20 \%$ was chosen for subsequent shake flask experiments.

\subsection{Screening Lysine Producers in Submerged Medium with Different Carbon and Nitrogen Sources}

The effects of carbon and nitrogen sources on growth and lysine production are presented in Figure 2. Of the carbon and nitrogen sources tested, glucose/ammonium sulphate $\left(\mathrm{NH}_{4}\right)_{2} \mathrm{SO}_{4}$ gave highest while crude oil/ $\mathrm{KNO}_{3}$ had the least lysine accumulation. Glucose/ammonium sulphate $\left(\mathrm{NH}_{4}\right)_{2} \mathrm{SO}_{4}$ was then used for further studies. Statistical analysis showed that there is significant difference on the occurrences of different sugar/nitrogen used $(\mathrm{P}$-value $=0.00)$.

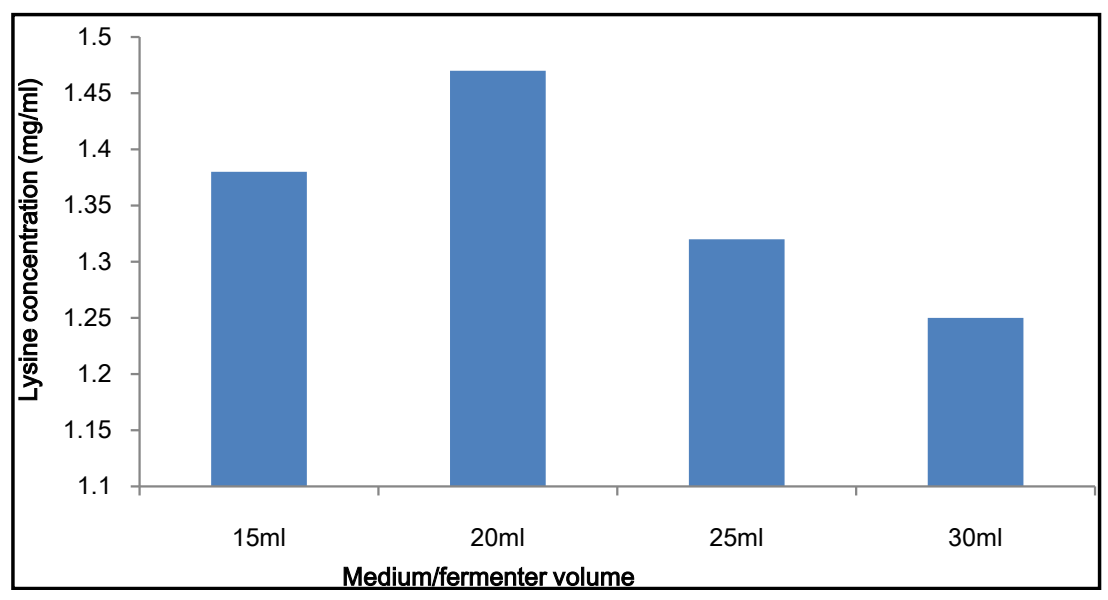

Figure 1. Effect of medium/fermenter volume ratio on lysine production. 


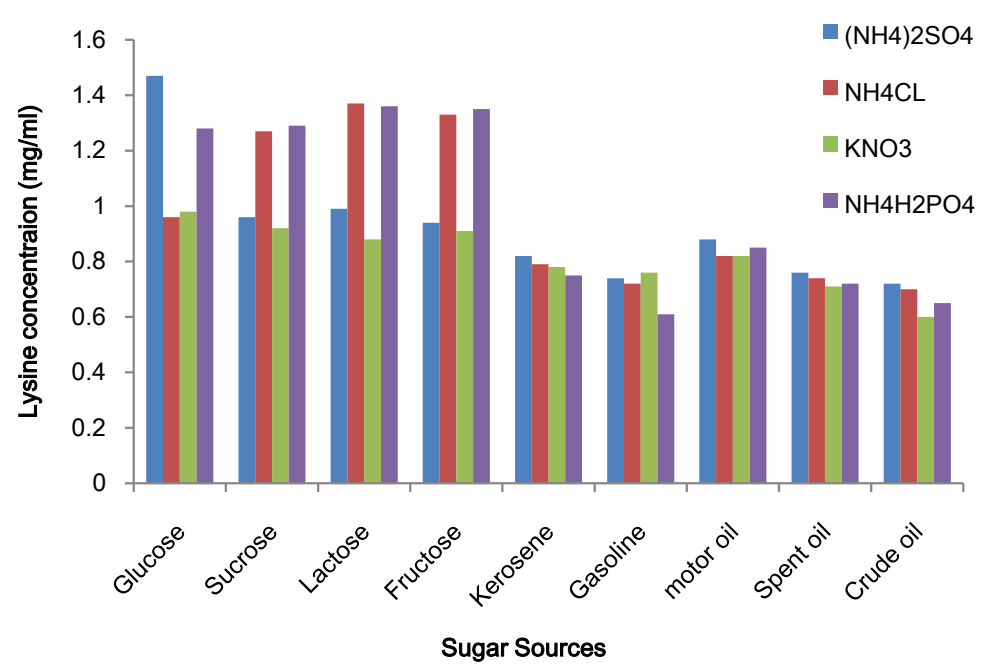

Figure 2. Effect of sources of sugar and nitrogen on lysine production in submerged medium.

\subsection{Effects of Varying Concentrations of Glucose on Growth and Lysine Production}

The result presented in Figure 3 shows the influence of varying concentrations of glucose on lysine production by Microbacterium lacticum. At $4 \%(\mathrm{w} / \mathrm{v})$ glucose concentration $1.68 \mathrm{mg} / \mathrm{ml}$ lysine accumulated in the culture broth. It also shows that lysine production increased as the glucose concentration increased, but decreased after more than $40 \mathrm{~g} / \mathrm{L}$ of glucose was added to the media. There is significant positive difference between glucose concentration and lysine concentration $(\mathrm{P}$-value $=0.00)$.

\subsection{Effects of Varying Concentrations of Ammonium Sulphate on Growth and Lysine Production}

Figure 4 shows the effects of varying concentrations of ammonium sulphate $\left(\mathrm{NH}_{4}\right)_{2} \mathrm{SO}_{4}$ on growth and lysine production. At $1 \%(\mathrm{w} / \mathrm{v})$ level of ammonium sulphate $\left(\mathrm{NH}_{4}\right)_{2} \mathrm{SO}_{4}$, $1.54 \mathrm{mg} / \mathrm{ml}$ of lysine yield was produced. Statistical analysis of the result shows that there is no significant difference between ammonium sulphate concentration and lysine concentration $(\mathrm{P}$-value $=0.008)$, thus as ammonium sulphate concentration increases, lysine production decreases and vice versa.

\subsection{Effect of Varying Concentrations Antibiotics on Growth and Lysine Production}

The effects of varying levels of antibiotics on growth and lysine production are presented in Figure 5. Antibiotics with the exception of tetracycline did not stimulate lysine production. Tetracycline at $0.05 \mu \mathrm{g} / \mathrm{ml}$ concentration gave lysine yield of 1.50 $\mathrm{mg} / \mathrm{ml}$. There is significant difference between in the different concentrations of antibiotics in relation to lysine production ( $\mathrm{P}$-value $=0.022$ ).

\subsection{Time Course of Fermentation for Growth and Lysine Production}

The time course of lysine production, growth and glucose utilization in submerged 
fermentation by Microbacterium lacticum are shown in Figure 5. As observed in Figure 6, there was rapid increase of lysine concentration after $24 \mathrm{~h}$ fermentation, decreasing to a concentration of $2.77 \mathrm{mg} / \mathrm{ml}$ after a period of $120 \mathrm{~h}$. The maximum growth and lysine accumulation of $2.95 \mathrm{mg} / \mathrm{m}$ was observed after $96 \mathrm{~h}$ fermentation and at the $\mathrm{pH}$ of 6.8 .

\section{Discussion}

Microbacterium lacticum used in this study, under submerged fermentation accumulated a lysine yield of $2.95 \mathrm{mg} / \mathrm{ml}$. No production of lysine by Microbacterium species has been reported. Although Sen and Chatterjee [20], Ekwealor and Obeta [18] noted that the yielding strains are found mostly among species of Arthrobacter, Corynebacterium, Brevibacterium and Bacillus.

Bacterial isolates from oil-contaminated and uncontaminated soil were investigated for lysine production. Among all the hydrocarbon used, it was be observed that kerosene was highly utilized while crude oil was the least utilized. Out of 104 hydrocarbon

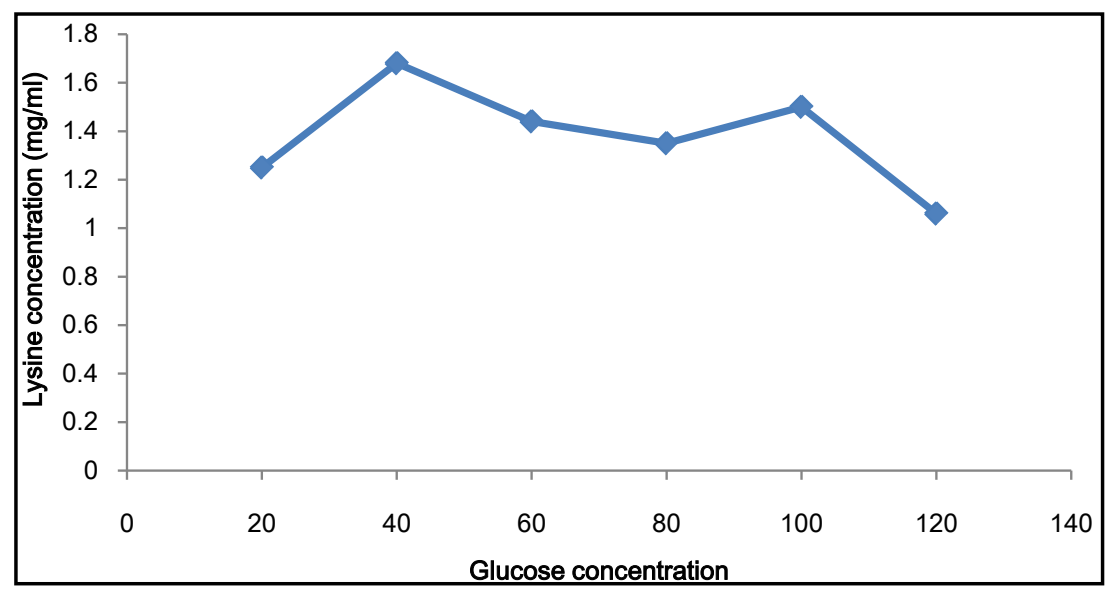

Figure 3. Effect of varying concentration on lysine production.

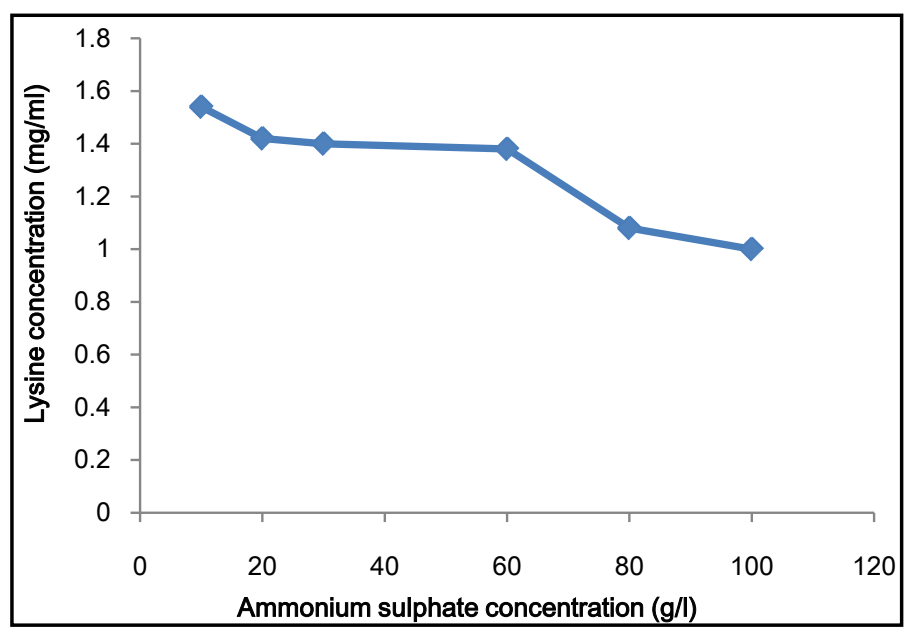

Figure 4. Effect of Ammonium sulphate on lysine production. 


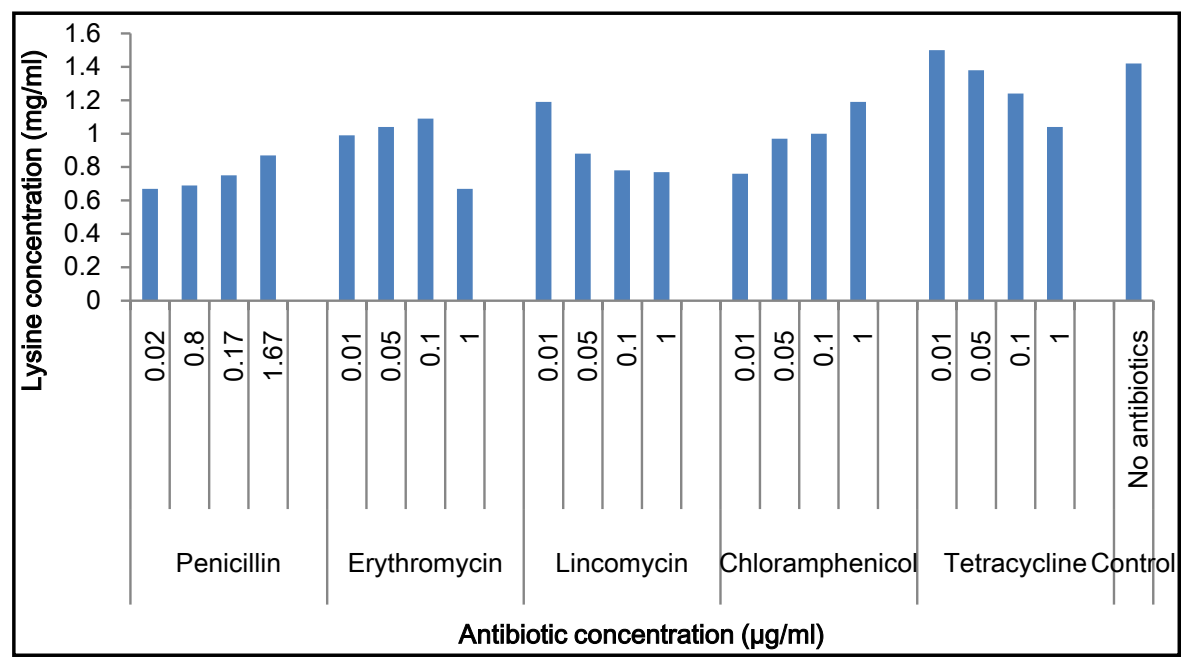

Figure 5. Effect of Antibiotics concentrations on lysine production.

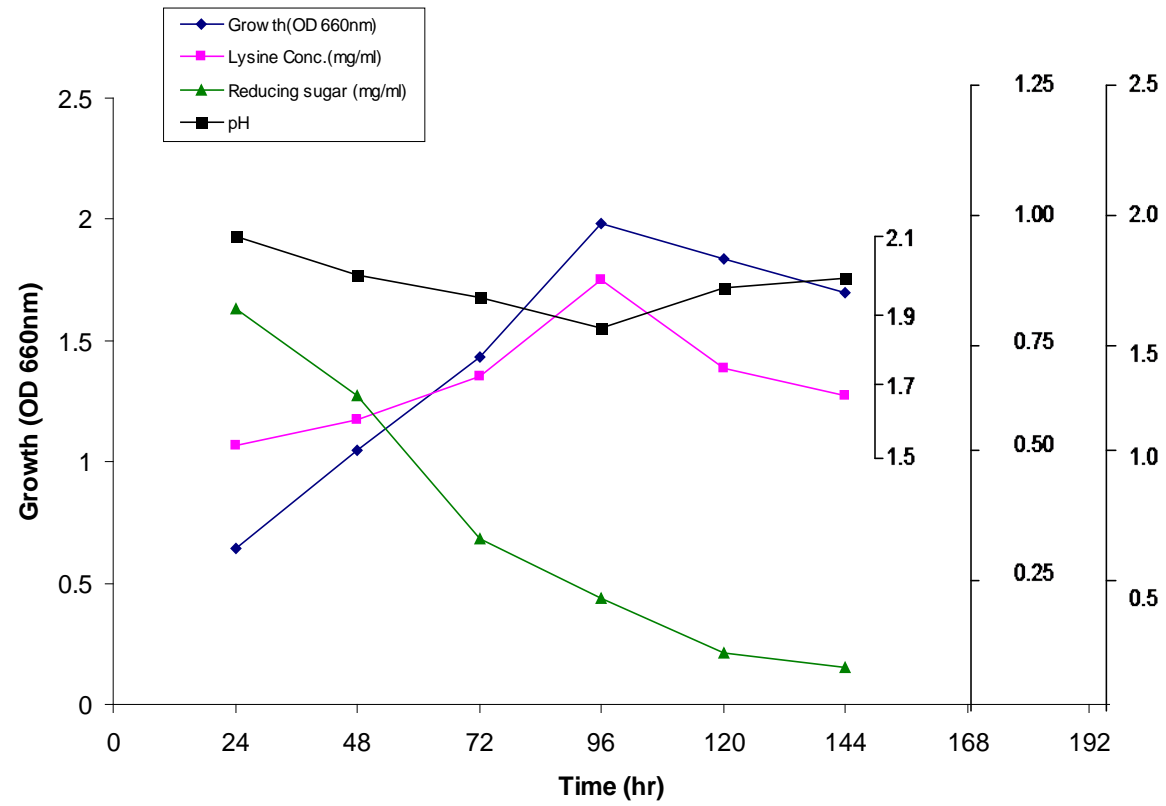

Figure 6. Time course experiment for growth, $\mathrm{pH}$, sugar utilization and lysine production.

utilizers, 16 were recovered as lysine producers, 11 of which were Gram +ve and 5 of them Gram -ve bacteria. That these organisms are present in the soil is in line with the findings of Ezemba et al. (2014a) who isolated hydrocarbon utilzer bacteria from oil-contaminated soil in Nigerian [28]. Also Ekwealor and Obeta (2005) were able to isolate lysine producer Bacillus megaterium sp14 from Nigerian soil [18]. Although Nwachukwu and Ekwealor, (2009) noted methionine-producing Streptomyces sp. can be isolated from Southern Nigerian soil [29].

In a taxonomic study, an active isolate that is Gram positive, irregular slender, utilizes citrate, urease, tyrosine and reduces nitrate. It was identified as Microbacterium lacticum, gave the highest lysine production and then studied. No production of lysine by 
Microbacterium species has been reported. Although Sen and Chatterjee (1989) noted that the yielding strains are found mostly among species of Arthrobacter, Corynebacterium and Brevibacterium [20].

The production of lysine from microorganism isolated from soil, agrees with the work of Ezemba, et al. (2014b) who noted a novel lysine producing bacterium from oilcontaminated soil [19]. Sen and Chatterjee (1989) also isolated Arthrobacter globiformis from Burdwan (Indian) soil that accumulated $3.4 \mathrm{~g} / \mathrm{l}$ of L-lysine [20]. Lysine producing bacteria were isolated from oil-contaminated soil and able to utilize hydrocarbon is in line with the work of Sen [30], who screened 263 hydrocarbon utilizer strains for their lysine production out of which only 24 isolates were lysine producers [30]. Ezemba, C.C. and Anakwenze, V.N. (2015) noted that hydrocarbon utilizers are fairly well distributed in oil-contaminated soil, and they also found 16 lysine producing organism out of 140 isolates [31].

There is need for adequate aeration in microbial production of metabolites (Khongsay et al. 2012) [32]. The results obtained with regard to oxygen tension (Figure 1) showed that as the liquid volume increased above $20 \mathrm{ml}$, methionine production decreased. Therefore, $20 \%$ is the optimum medium/fermenter volume ratio for methionine accumulation in submerged culture of Microbacterium lacticum. This finding is supported by the work of Pham et al. (1992) who observed $20 \%$ fermenter volume give the highest production of methionine [33]. The influence of medium composition on lysine accumulation in a culture broth was reported by Sassi et al. [34]. Anastassiads (2007), however, noted that in addition to physiochemical parameters, medium composition is very important factor strongly influencing fermentation processes, often being of extensive process development and optimization [12]. According to Anastassiads (2007), culture medium must satisfy in a suitable manner the requirement of microbial growth and production [12].

In a shake flask fermentation experiment using different carbon and nitrogen source medium, production of lysine by these bacteria were determined (Figure 2). High lysine yield in Microbacterium species of $1.47 \mathrm{mg} / \mathrm{ml}$ with Glucose/Ammonium sulphate agrees with work of Ezemba et al. (2014c), who noted that a Microbacterium lacticum a hydrocarbon utilizers accumulated a high quality of lysine in shake flask fermentation in addition with B-vitamin and Metals [35]. Also this is supported by the work of Kinoshita et al. (1958); Sen and Chatterjee [37] and Ezemba, et al. (2014b, c) [19] [35][37]. Sen and Chatterjee [37] isolated Arthrobacter globiform is that is capable of accumulating L-lysine in purely synthetic medium [37]. This is contrary to the work of Ekwealor and Orafu, (2003), who also noted that Bacillus sp. accumulated lysine in broth culture [10]. The difference in production may be due to difference in cultural conditions and the organism used. The production of lysine by Microbacterium lacticum, in submerged fermentation had the highest lysine concentration $(1.44 \mathrm{mg} / \mathrm{ml})$ and was for used further studies.

The ability of Microbacterium lacticum, to use hydrocarbon as carbon source and able to produce lysine was very successful. However a very low lysine yield was produced when hydrocarbon were used as a carbon sources. We suggests that Microbacte- 
rium lacticum, has a role to play in bioremediation and that fermentation medium and process variable if improved on may likely result in maximum lysine.

The contributory factors to low yield of lysine when hydrocarbon was used as carbon source (Figure 2) could be attributed to the regulatory mechanism factors that limit the growth of hydrocarbon- oxidizing bacteria, this is supported by Atlas (1981) [38] and other investigators (Anastassiadis, 2007) [12], who citied that when olefin and ethyl alcohol are used as carbon source for genus Nocardia low yield of lysine was obtained.

Carbon sources and their ratio in fermentation media play a significant role in the production of a particular metabolite (Gomes and Kumar, 2005) [39].

The use of glucose as the carbon source (Figure 3 ) of choice for amino acid production by Microbacterium lacticum is in line with the work of several researchers (Dike and Ekwealor, 2012; Anakwenze et al. 2014; Ezemba et al. 2014b, c) [16] [19] [35] [40]. It also shows that lysine production was a function of the initial sugar concentration in the fermentation medium (Ekwealor and Obeta, 2005), who demonstrated that a high L-lysine producer, high-glucose-consumer could be from fusion of a high-L-lysine, low glucose strain with a low L-lysine, highly glucose strain [18].

Based on the result in Figure 4, lysine production was observed to be a function of nitrogen concentration up to $1 \%$ beyond which accumulation of lysine decreased

The stimulation of lysine by ammonium sulphate in the culture broth of Microbacterium lacticum is supported by the works of Ekwealor and Obeta (2005); Ezemba et al. (2014b, c) [18] [19] [35]; for lysine production and Mondal et al. 1994, Kumar et al. 2005, Anike and Okafor 2008; Dike and Ekwealor 2012; Ozulu et al. 2012 for L-methionine production [40]-[44].

As presented in Figure 4, lysine accumulation by Microbacterium lacticum was obtained at $1 \%$ level of ammonium sulphate. Thus, as the ammonium sulphate concentration increases lysine production decreases and vice versa. Anakwenze et al. (2014) reported that $1 \%$ concentration of ammonium sulphate by Bacillus cereus $\mathrm{S} 8$ gave highest yield of methionine [16]. This work is contrary to the work of Ekwealor and Obeta (2005), who noted at $2 \%$ level of nitrogen sources gave the highest lysine yields by B.megaterium SP-14 [18]. This decrease, as suggested by Pham et al. (1992), may be attributed to osmotic pressure exerted by high nitrogen concentration, which may have adversely affected the organism's growth and lysine accumulation [33].

The effects of varying levels of antibiotics on lysine production are presented in Figure 5. Antibiotics with the exception of tetracycline did not stimulate lysine production. Tetracycline at $0.05 \mu \mathrm{g} / \mathrm{ml}$ concentration gave lysine yield of $1.50 \mathrm{mg} / \mathrm{ml}$. This is contrary with the work of Ekwealor and Obeta who observed lincomycin improved lysine yield in Bacillus megaterium18.

The reports regarding increased lysine production by bacteria, in the presence of small quantities of several kinds of antibiotics were investigated in Microbacterium lacticium [30] [37] [45]-[48]. Erythromycin, chloramphenicol, lincomycin, and penicillin did not stimulate lysine production, but at $0.05 \mu \mathrm{g} / \mathrm{ml}$ concentration tetracycline gave a yield of $(1.50 \mathrm{mg} / \mathrm{ml})$. This is in line with the reports of Zaki, et al. (1982) who found that some $22-24 \mathrm{~g} / \mathrm{L}$ could be produced by Micrococcus glutamicium, when tetracyc- 
line and erythromycin were added to the fermentation culture [45]. Furthermore antibiotics could be used to arrest such free cell growth while allowing the synthesis and excretion of the product into the medium [46] and also to maintain the stability of plasmids in the medium [47]. The inhibitory effect of other antibiotics as suggested by Israilides, et al. [46], may probably be due to great decrease in cell viability of Microbacterium lacticum which also prevented the production of lysine [46].

A similar relationship between sugar consumption and amino acid production by Micrococcus glutamicum has been reported by Murgov and Zaitseva (1973) [49]. The possible application of various requirements for the growth and production of lysine by Microbacterium lacticm in (Figure 6) were study in the time-course fermentation process accompanied by sugar utilization and $\mathrm{pH}$. The highest level of lysine produced was $2.95 \mathrm{mg} / \mathrm{ml}$ after $96 \mathrm{~h}$ fermentation. This result is comparable to the reports of Ekwealor and Obeta (2005) that reported that Bacillus megaterium accumulated a lysine

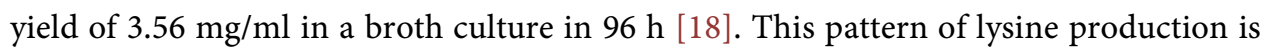
similar to that observed in the works of Pham et al. (1992) and Anakwenze et al. (2014) on methionine production [16] [33].

\section{Conclusion}

In summary, the present results show a marked improvement of the lysine fermentation by hydrocarbon utilizer, in its yield as well as the fermentation time. The fermentation process for the production of lysine by Microbacterium lacticum was successfully assessed in shake flasks on a laboratory scale. Glucose and Ammonium sulphate served as a good carbon and nitrogen sources, respectively, for high lysine yield. Synthetic sources were better than the hydrocarbon source, because lysine production also applies with the works of Ezemba, et al. 2015; Ezemba and Anakwenze, 2015 [31] [50]. It is concluded that the physiological significance of amino acid production by microorganisms is uncertain, though a pathological rather than a physiological process takes place in the producer organisms [51]. Generally, amino acid producing microorganism is subjected to negative feedback regulations, which results poor yield under normal condition, as required by the cells. Thus, future of the lysine fermentation by hydrocarbon utilizer will be very promising using mutation techniques, recombinant DNA technology and process development and optimization as suggested by Anastassiadis, $\mathrm{S}$. (2007) to improve and channel into a wide range of application and the information obtained can be used for the development of biotechnology for maximum accumulation of lysine and bioremediation [12] Also submerged fermentation process of lysine production when developed will reduce importation of lysine in Nigeria and make it more readily available.

\section{References}

[1] Shan, A.H., Hameed, A. and Khan, G.M. (2002) Review Article on Fermentation Production of L-Lysine: Bacterial Fermentation-1. Journal of medical Science,2, 152-157. http://dx.doi.org/10.3923/jms.2002.152.157

[2] Stilling, B.R., Sidwell, V.D. and Hammerle, O.A. (1971) Nutritive Quality of Wheat Flour 
and Bread Supplement with Either Fish Protein Concentrate or Lysine. Cereal Chemistry, 48, 292-302.

[3] Wikipedia (2014) A Free Encyclopedia. http://en.Wikipedia.org/wiki/lysine

[4] Crueger, W. and Annelise, C. (1990) Biotechnology: A Textbook of Industrial Microbiology. 2nd Edition, USA.

[5] Pape, F. (2003) The Essential Amino Acid, Lysine, Acts as Precursor of Glutamate in Mammalian Central Nervous System. FEBS Letters, 488, 34-38. http://dx.doi.org/10.1016/S0014-5793(00)02401-7

[6] Ezemba, C.C. and Ogu, C.T. (2015) Isolation and Characterization of Lysine Producing Bacteria from Palm Wine. Journal of Educational Research, 3, 230-240.

[7] Kobayashi, K. and Nishikawa, M. (2006) Promotion of E-Poly-L-Lysine Production by Iron in Kitasatospora kifuence. World Journal of Microbiology and Biotechnology, 10, 10331036.

[8] Schrumpf, B., Eggeling, L. and Sahm, H. (1992) Isolation and Prominent Characteristics of a L-Lysine Hyper Producing Strain of Corynebacterium glutamicum. Applied Microbiology and Biotechnology, 37, 566-571. http://dx.doi.org/10.1007/BF00240726

[9] Eggeling, L. (1994) Biology of L-Lysine Over-Production by Corynebacterium glutamicum. Amino Acids, 6, 261-272. http://dx.doi.org/10.1007/BF00813746

[10] Ekwealor, I.A. and Orafu, A.E. (2003) Preliminary Study of L-Lysine Production of Bacillus Species Using Various Agricultural By-Products. Food, 47, 226-227.

[11] Kinoshita, S., Udaka, S. and Shimono, M. (1957) Studies on Amino Acid Fermentation Production of L-Glutamic Acid by Various Microorganisms. Journal of General and Applied Microbiology, 3, 193-205. http://dx.doi.org/10.2323/jgam.3.193

[12] Anastassiadis, S. (2007) L-Lysine Fermentation. Research Article. Resent Patents on Biotechnology, 1, 11-24.

[13] Anonymous (2014) Amino Acids. Chemistry of Amino Acids, Assessed on May 2014.

[14] Okamoto, K., Kino, K. and Ikeda, M. (2000) Hyper Production of L-Threonine by an Escherichia coli Mutant with Impaired L-Threonine Uptake. Biosciences Biotechnology Biochemistry, 61, 1877-1882. http://dx.doi.org/10.1271/bbb.61.1877

[15] Hermann, T. (2003) Industrial Production of Amino Acids by Coryneform Bacteria. Journal of Biotechnology, 104, 155-172. http://dx.doi.org/10.1016/S0168-1656(03)00149-4

[16] Anakwenze, V.N., Ezemba, C.C. and Ekwealor, I.A. (2014) Optimization of Fermentation Conditions of Bacillus thuringiensis ECI for Enhanched Methionine Production. Advances in Microbiology, 4, 344-352. http://dx.doi.org/10.4236/aim.2014.47041

[17] Ezemba, C.C. (2008) Lysine Production by Microbacterium lacticum. A MSc Project, Department of Microbiology, Nnamdi Azikiwe University, Awka.

[18] Ekwealor, I.A. and Obeta, J.A.N. (2005) Studies on Lysine Production by Bacillus megaterium. African Journal of Biotechnology, 4, 633-638. http://dx.doi.org/10.5897/AJB2005.000-3115

[19] Ezemba, C.C., Ekwealor, I.A., Ozokpo, C.A., Chukwujekwu, C.E. and Anakwenze, V.N. (2014) Influence of Amino Acids and Growth Promoting Factors on Lysine Production by Microbacterium lacticum. International Journal of Current Research in Biosciences and Plant Biology, 1, 71-74.

[20] Sen, S.K. and Chatterjee, M. (1989) Influence of B-Vitamins and Trace Elements on Lysine Production by Micrococcus varians 2Fa. Acta Biotechnologica, 9, 63-67.

[21] Ward, D.M. and Brock, T.D. (1976) Environmental Factor Influencing the Rate of Hydrocarbon Oxidation in Temperate Lake. Applied and Environmental Microbiology, 31, 764- 
772.

[22] Halsall, D.M. (1975) Overproduction of Lysine by Mutant Strains of Escherichia coli with Defective Lysine Transport System. Biochemical Genetics, 13, 109-125. http://dx.doi.org/10.1007/BF00486010

[23] Chinard, F.D. (1952) Photometric Estimation of Proline and Ornithine. Journal of Biological Chemistry, 199, 91-95.

[24] Miller, G.L. (1959) Use of Dinitrosalicylic Acid Regent for Detection of Reducing Sugars. Analytical Chemistry, 31, 427-431. http://dx.doi.org/10.1021/ac60147a030

[25] Buchanan, R.E. and Gibbon, N.E. (1974) Bergey's Manual of Determinative Bacteriology. 9th Edition, Williams and Wilkins Co., Baltimore.

[26] Fineglod, S.M. and Baton, E.J. (1990) Barley and Scotta Diagnosic Microbiology. 8th Edition, the C.V Mosby Co., Maryland Heights.

[27] Barrow, G.I. and Feltham, R.K.A. (1993) Cowan and Steels Manual for the Identification of Medical Bacteria. 3rd Edition, Cambridge University Press, Cambridge. http://dx.doi.org/10.1017/CBO9780511527104

[28] Ezemba, C.C., Ekwealor, I.A., Ozokpo, C.A. and Chukwujekwu, C.E. (2014) Isolation and Characterization of Hydrocarbon Utilizing Microorganism. Contemporary Journal of Educational Research (COJER), 4, 407-414.

[29] Nwachukwu, R. and Ekwealor, I.A. (2009) Methionine Producing Streptomyces Species Isolated from Southern Nigeria Soil. African Journal of Microbiology Research, 3, 478-481.

[30] Sen, S.K. (1985) Isolation Method of Lysine over Producers from Hydrocarbon Utilizer. Acta Biotechnologica, 5, 379-381. http://dx.doi.org/10.1002/abio.370050415

[31] Ezemba, C.C. and Anakwenze, V.N. (2015) Lysine Production by Hydrocarbon Utilizing Bacteria. Journal of Educational Research, 3, 241-248.

[32] Khongsay, N., Laopaiboon, L., Jaisil, P. and Laopaiboon, P. (2012) Optimization of Agitation and Aeration for Very High Gravity Ethanol Fermentation from Sweet Sorghum Juice by Saccharomyces cerevisiae Using an Orthogonal Array Design. Energy, 5, 561-576.

[33] Pham, C.B., Galves, F.C.F. and Padolina, W.G. (1992) Methionine Production by Batch Fermentation from Various Carbohydrates. ASEAN Food Journal, 7, 34-37.

[34] Sassi, A.H., Coello, N., Deschamps, A.M. and Lebeault, J.M. (1990) Effect of Medium Composition on L-Lysine Production by a Variant Strain of Corynebacterium glutamicum ATCC 21513. Biotechnology Letters, 12, 295-298. http://dx.doi.org/10.1007/BF01093524

[35] Ezemba, C.C., Ekwealor, I.A., Ozokpo, C.A., Chukwujekwu, C.E. and Anakwenze, V.N. (2014) Stimulating Effect of B-Vitamins and Bivalent Metals on Lysine Accumulation by Microbacterium lacticum. International Journal of Biosciences, 5, 18-23. http://dx.doi.org/10.12692/ijb/5.12.18-23

[36] Kinoshita, S., Nakayama, K. and Kitada, S. (1958) L-Lysine Production Using Microbial Auxotroph. Journal of General Applied Microbiology, 4, 128-129. http://dx.doi.org/10.2323/jgam.4.128

[37] Sen. S.K. and Chatterjee, M. (1983) L-Lysine Production from Hydrocarbons by Micrococcus varians $2 \mathrm{Fa}$. Acta Biotechnologica, 32, 139-145.

[38] Atlas, R.M. (1981) Microbial Degradation of Petroleum Hydrocarbon: An Environmental Perspective. Microbiological Reviews, 45, 180-209.

[39] Gomes, J. and Kumar, D. (2005) Production of L-Methionine by Submerged Fermentation: A Review. Enzyme and Microbial Technology, 37, 3-18. http://dx.doi.org/10.1016/j.enzmictec.2005.02.008 
[40] Dike, K.S., Ekwealor, I. and Eziuzor, S.C. (2013) Influence of Antibiotics and Surfactants Addition on Growth and Methionine Productivity by Bacillus cereus. Advances in Microbiology, 3, 26-31. http://dx.doi.org/10.4236/aim.2013.31004

[41] Mondal, S., Das, Y.B. and Chatterjee, S.P. (1994) L-Methionine Production by Double Auxotrophic Mutants of an Ethionine Resistant Strain of Brevibacterium heali. Acta Biotechnologica, 14, 61-66. http://dx.doi.org/10.1002/abio.370140111

[42] Kumar, D., Subramanian, K., Bisaria, V.S., Sreekrishnan, T.R. and Gomes, J. (2005) Effect of Cysteine on Methionine Production by a Regulatory Mutant of Corynebacterium lilium. Bioresource Technology, 96, 287-294. http://dx.doi.org/10.1016/j.biortech.2004.04.011

[43] Anike, N. and Okafor, N. (2008) Secretion of Methionine by Microorganisms Associated with Cassava Fermentation. African Journal of Food, Agriculture, Nutrition and Development, 8, 77-90. http://dx.doi.org/10.4314/ajfand.v8i1.19181

[44] Ozulu, U.S., Nwanah, O.U., Ekwealor, C.C., Dike, S.K., Nwikpo, C.L. and Ekwealor, I.A. (2012) A New Approach to Screening for Methionine-Producing Bacteria. British Microbiology Research Journal, 2, 36-39. http://dx.doi.org/10.9734/BMRJ/2012/989

[45] Zaki, D., Galah, O., Waliba, S., Morsi, K. and EL-Wakail, F.A. (1982) Microbiological Production of Lysine. Nutrition Reports International, 26, 537-546.

[46] Israilides, C.J., Weir, A.N. and Bull, A.T. (1989) Effect of Antibiotics on Lysine Production in Free and Immobilized Cells of Bacillus subtilis. Applied Microbiology and Biotechnology, 32, 134-136. http://dx.doi.org/10.1007/BF00165876

[47] Reynen, C., Haederich, B., Pfefferie, W., Eggeling, L., Sahm, H. and Patek, M. (2006) New Coryneform Bacteria for Fermentation Production of L-Lysine, Especially for Use as Feed Additive, Containing Amplified Pyc Gene and Amplified DapA Gene with Specific Mutated promoter. EP161925248.

[48] Ekwealor, I.A. and Obeta, J.A.N. (2008) Antibiotics and Surfactant Effects on Lysine Production of Bacillus megaterium. African Journal of Biotechnology, 7, 1550-1553.

[49] Murgov, I.D. and Zaitseva, Z.M. (1973) The Effect of the Components of the Nutrient Medium on the Biosynthesis of Lysine by a Homoserine Deficient Mutant of Brevibacterium flavum. Prikladmays Biokhimiya Mikrobiologiya, 9, 356-361.

[50] Ezemba, C.C., Ekwealor, C.C., Ekwealor, I.A., Ozokpo, C.A., Chukwujekwu, C.E., Anakwenze, V.N., Archibong, E.J. and Anaukwu, G.C. (2015) Microbacterium Lacticum; A Lysine Producing Bacterium Isolated from Oil-Contaminated Soil in South-East Nigeria. British Microbiology Research Journal, 9, 885-895. http://dx.doi.org/10.9734/BMRJ/2015/15168

[51] Neijsell, D.M., Mattos, M. and Tempest, D.W. (1993) Overproduction of Metabolites. In: Pelezar, M.J., Schan, E.C. and Krieg, N.R., Eds., Microbiology Concepts and Applications, University Press, Cambridge, 163-187. http://dx.doi.org/10.1002/9783527620821.ch4 
Submit or recommend next manuscript to SCIRP and we will provide best service for you:

Accepting pre-submission inquiries through Email, Facebook, LinkedIn, Twitter, etc. A wide selection of journals (inclusive of 9 subjects, more than 200 journals)

Providing 24-hour high-quality service

User-friendly online submission system

Fair and swift peer-review system

Efficient typesetting and proofreading procedure

Display of the result of downloads and visits, as well as the number of cited articles

Maximum dissemination of your research work

Submit your manuscript at: http://papersubmission.scirp.org/ 